\title{
PENGATURAN HUKUM POSITIF INDONESIA TENTANG INVESTASI BODONG (FOREX ILEGAL)
}

\author{
Lie Natanael ${ }^{1}$, Cindy Cintya Lauren ${ }^{2}$, Della Kristina ${ }^{3}$, Tatang Ruchimat ${ }^{4}$ \\ ${ }^{1}$ Jurusan Hukum, Universitas Tarumanagara Jakarta \\ Surel; natanael.205210135@stu.untar.ac.id \\ ${ }^{2}$ Jurusan Hukum, Universitas Tarumanagara Jakarta \\ Surel: cindy.205210047@stu.untar.ac.id \\ ${ }^{3}$ Jurusan Hukum, Universitas Tarumanagara Jakarta \\ Surel: della.205210037@stu.untar.ac.id \\ ${ }^{4}$ Jurusan Hukum, Universitas Tarumanagara Jakarta \\ Surel: tatangr@fh.untar.ac.id
}

\begin{abstract}
Fake investment is becoming a phenomenon that has been occurring a lot lately in Indonesia, especially the online kind. Investment is a commitment to invest some fund to one or more asset(s) in some period of time. This article is written with a goal to do research on law enforcement of Indonesian investment law. The method of research that is used is normative law research. It's found that: Investment in Indonesia is regulated by the Law of The Republic of Indonesia number 25 of 2007 on Capital Investments. System of investing in Indonesia is protected by Law of The Republic of Indonesia number 10 of 1998. The presence of fake investment is bringing negative influence to Indonesian investment scene. Act of fraud or embezzlement in the form of investments can be prosecuted criminally and sentenced up to 4 years of imprisonment according to the Indonesian criminal code article 372 and 378 . It is to be expected that public can differentiate which is a legal and which is a fake investment. That could be realized if the public is educated on economics and law. It is a joint responsibility of the government, investment organizers, and academics.
\end{abstract}

Keywords: Law, investment, fake

ABSTRAK
Investasi bodong menjadi sebuah fenomena yang sering terjadi belakangan ini sangat marak terjadi di Indonesia, khususnya investasi online. Investasi merupakan komitmen menanamkan sejumlah dana pada satu atau lebih aset selama beberapa periode. Artikel ini dibuat dengan tujuan untuk meneliti penegakkan hukum tentang investasi di Indonesia. Metode yang digunakan adalah penelitian hukum normatif. Dan ditemukan bahwa: Investasi di Indonesia diatur dalam Undang-Undang No. 25 Tahun 2007 Tentang Penanaman Modal. Sistem investasi di Indonesia dilindungi oleh UU No. 10 tahun 1998 tentang Perubahan Undang-undang Nomor 7 Tahun 1992 tentang Perbankan. Kehadiran investasi bodong membawa pengaruh negatif bagi iklim investasi Indonesia. Tindakan penipuan dan penggelapan uang yang berkedok investasi dapat dijerat pidana penjara paling lama empat tahun sesuai Pasal 372 dan 378 UU KUHP. Diharapkan kedepannya masyarakat dapat membedakan mana investasi yang legal dan yang bodong. Hal itu dapat terjadi bila masyarakat teredukasi soal ekonomi dan hukum. Ini menjadi tanggung jawab bersama pemerintah, penyelenggara investasi, dan akademisi.

Kata Kunci: Hukum, investasi, bodong

\section{PENDAHULUAN}

\section{Latar Belakang}

Pertumbuhan investor dalam masa pandemi seolah ladang hijau bagi para mafia investasi bodong. Dilansir dari CNBC Indonesia (CNBC Indonesia, 2021), Satgas Waspada Investasi mencatat kerugian masyarakat yang ditimbulkan dari praktik ilegal investasi bodong dalam kurun waktu 10 tahun terakhir menembus angka Rp 117 triliun. Investasi bodong tentu bertentangan dengan tujuan utama investasi itu sendiri. Bukannya memperlancar pergerakan ekonomi negara, malah justru menjadi tembok tinggi yang menghambat ekonomi. Kepatuhan lahir dari adanya kepekaan dan wawasan masyarakat akan hukum. Hal ini tentu penting untuk mewujudkan perlindungan yuridis bagi pihak yang terlibat dalam kegiatan investasi. Tahun 2019 
terjadi 442 kasus investasi bodong, dan pada tahun 2020 mencapai hingga 349 kasus, hingga maret 2021 terdapat 42 kasus (CNBC Indonesia, 2021).

Menurut ketentuan Pasal 16 Ayat 1 UU No. 10 Tahun 1998 Tentang Perubahan Atas Undangundang Nomor 7 Tahun 1992 Tentang Perbankan yang menyatakan:

"Setiap pihak yang melakukan kegiatan menghimpun dana dari masyarakat dalam bentuk simpanan wajib terlebih dahulu memperoleh izin usaha sebagai Bank Umum atau Bank Perkreditan Rakyat dari Pimpinan Bank Indonesia, kecuali apabila kegiatan menghimpun dana dari masyarakat dimaksud diatur dengan Undang-undang tersendiri."

Selanjutnya ketentuan Pasal 46 Undang-Undang Nomor 10 Tahun 1998 Tentang perbankan menyatakan:

"Barang siapa menghimpun dana dari masyarakat dalam bentuk simpanan tanpa izin usaha dari Pimpinan Bank Indonesia sebagaimana dimaksud dalam Pasal 16, diancam dengan pidana penjara sekurang-kurangnya 5 (lima) tahun dan paling lama 15(lima belas) tahun serta denda sekurang-kurangnya Rp10.000.000.000,00 (sepuluh miliar rupiah) dan paling banyak Rp 20.000.000.000,00 (dua puluh miliar rupiah)."

Minimnya kesadaran hukum masyarakat membuka celah bagi mafia investasi untuk menghimpun dana tak berizin. Meskipun secara konstitusional investasi bodong telah diatur, banyak masyarakat awam yang tidak mengerti langkah yang harus dilakukan untuk membedakan investasi yang sah dan yang bodong. Pemahaman tentang hukum dan kesadaran mengenai hukum bagi para investor menjadi bagian yang sangat penting karena dengan memahami tentang hukum dapat mengetahui kepatuhan dan perlindungan hukum terhadap para investor dan pihak yang terkait. Hukum investasi ini sangat berkaitan dengan peraturan dasar hukum perbankan yang secara tegas mengancam para pelaku investasi bodong ancaman pidana penjara dan denda terhadap pelaku investasi bodong.

\section{Rumusan Masalah}

1. Bagaimana ketentuan-ketentuan hukum yang berlaku di Indonesia tentang praktik investasi bodong (forex ilegal)?

2. Apa bentuk perlindungan hukum Negara Indonesia bagi masyarakat dalam menghadapi investasi bodong (forex ilegal)?

\section{METODE PENELITIAN}

Metode penelitian yang digunakan adalah metode penelitian hukum normatif. Soerjono Soekanto dan Sri Mamudji menjelaskan bahwa pada penelitian hukum normatif, data dasar yang digunakan adalah bahan pustaka yang dalam ilmu penelitian tergolong sebagai data sekunder yang meliputi bahan hukum primer, bahan hukum sekunder, dan bahan hukum tersier. Seluruh data yang didapat selanjutnya diolah dan dianalisis secara kualitatif untuk mendapatkan pemahaman terhadap gejala-gejala yang diteliti.

\section{HASIL DAN PEMBAHASAN}

\section{Hukum tentang Investasi Bodong di Indonesia}

Kamus Besar Bahasa Indonesia menerjemahkan investasi sebagai kegiatan penanaman uang atau modal yang bertujuan untuk memperoleh keuntungan dan umumnya modal ditanamkan dalam badan usaha atau proyek. Dalam pemahaman Van Horne (1986), kegiatan pemanfaatan kas pada masa saat ini (present) untuk menghasilkan profit di masa depan (future). Sedangkat BEI menjelaskan bahwa, investasi adalah kegiatan yang bertujuan untuk melawan pengurangan nilai uang akibat inflasi. Kamarauddin (2004) menjelaskan investasi adalah suatu kegiatan memindahkan dana ke dalam bentuk saham, surat utang, atau surat lainnya. Di sisi lain, juga dapat didefinisikan sebagai aktivitas membeli barang-barang modal dengan memanfaatkan dana 
yang tersedia untuk digunakan dalam produksi demi pendapatan di masa depan. Kegiatan penanaman modal asing diatur dalam Undang-Undang Nomor 25 Tahun 2007 yang isinya tentang ketentuan-ketentuan pihak asing yang ingin melakukan Penanaman Modal di Indonesia baik itu dilakukan oleh warga negara asing, badan usaha asing dan/atau pemerintahan asing.

Pengaturan hukum tentang investasi dapat diajukan oleh Presiden. Hal ini sejalan dengan UUD NRI Tahun 1945. Dalam Undang-Undang Dasar, pembangunan nasional adalah sesuatu yang krusial dalam kemajuan perekonomian Negara Indonesia yang tentu bertujuan untuk secara berkelanjutan memperbaiki ekonomi nasional. Hal yang harus diperhatikan adalah, pembangunan dan perbaikan ekonomi Indonesia tentu harus berlandaskan paham demokrasi ekonomi Indonesia. Investasi adalah salah satu langkah yang harus dilakukan dalam pembangunan ekonomi bangsa. Sejalan dengan mandat yang diberikan oleh Ketetapan Majelis Permusyawaratan Rakyat Republik Indonesia Nomor XVI/MPR/1998 yang berkaitan dengan pelaksanaan aturan dan kebijakan investasi (penanaman modal) yang berasaskan sistem ekonomi kerakyatan. Sistem ekonomi kerakyatan tersebut melibatkan beragam jenis pelaku ekonomi yang terdiri dari UMKM (Usaha Menengah Kecil dan Mikro) dan Koperasi). Penanaman modal dilakakukan dengan tujuan untuk mempercepat konstruksi ekonomi. Hal ini dilakukan dengan tujuan agar potensi ekonomi masyarakat dapat berubah menjadi pergerakan ekonomi yang nyata. Sumber dari penanaman modal ini tidak selalu harus dari luar negeri, melainkan juga harus memberdayakan sumber dalam negeri. Namun sebelum terjun ke dalam pasar global dan melakukan kerjasama internasional, langkah penting yang harus dilakukan adalah untuk menciptakan iklim investasi. Tidak cukup sampai disana, iklim tersebut harus terus dijaga agar tetap kondusif dan produktif. Sifat lain yang harus dimiliki iklim investasi Indonesia adalah iklim yang menjual, efisien, dan terlebih lagi tetap mementingkan masyarakat Indonesia.

Kepastian hukum adalah salah satu poin pertimbangan penting yang ada di dalam pertimbangan investor jika ingin melakukan investasi di suatu negara. Mengapa kepastian hukum menjadi penting? Karena investasi bukanlah kegiatan jangka pendek, investasi adalah kegiatan yang memerlukan waktu karena tujuannya adalah keuntungan di masa depan. Bila selama modal ditanamkan di suatu negara dan negara tersebut tidak memiliki kepastian hukum, maka investor tidak dapat memperhitungkan seberapa keuntungan atau bahkan kerugian yang terjadi karena hukum yang mengaturnya terus berubah. Ketidakpastian adalah musuh dari investasi, semakin besar ketidakpastiannya, maka semakin enggan investor untuk melakukan investasi. Untuk mengatasi hal ini, Pemerintah Indonesia menghadirkan jawaban untuk menyelesaikan permasalahan ketidakpastian hukum yang mungkin terjadi sebelumnya. Untuk melakukan hal ini, pemerintah harus membuat peraturan yang dapat menyelaraskan peraturan-peraturan yang tumpang tindih atau bahkan berlawanan. Konsep peraturan yang menyelaraskan peraturanperaturan ini dikenal dengan sebutan Omnibus Law. Menggunakan konsep ini, Pemerintah Indonesia merumuskan Undang-Undang Cipta Kerja No. 11 Tahun 2020. Kehadiran undangundang ini tidak kemudian secara langsung menyelesaikan permasalahan kepastian hukum. Selain regulasi, kepastian hukum juga berbicara tentang penegakan hukum. Selain penyelarasan regulasi, UU Cipta Kerja juga diharapkan dapat menciptakan iklim investasi yang memadai dan dapat bersaing dengan negara-negara lain. Faktor lain yang juga mempengaruhi investor dalam melakukan kegiatan penanaman modal adalah kemudahan dan insentif yang diberikan. Pemerintah Indonesia juga tentu harus menjawab permintaan ini.

Kehadiran investasi bodong atau forex ilegal di Indonesia berkembang dengan subur dan terus bermunculan di berbagai tempat dan level masyarakat. Korban dan kerugian yang dihasilkan pun sudah banyak, namun entitas seperti ini terus hadir dan justru bertambah banyak. Kasus yang melibatkan seorang nasabah yang merasa tertipu karena sebuah layanan asuransi meramaikan perbincangan di beberapa portal berita dan sosial media. Modusnya dengan menawarkan imbal hasil investasi yang besar. Kemajuan teknologi dan tersedianya platform investasi online 
dimanfaatkan sebagai celah untuk berkembangnya investasi bodong (Primantari \& Sarna, 2014). Data Satgas Waspada Investasi (SWI) mencatat setidaknya ada 390 kegiatan investasi ilegal dan 1.200 fintech bodong yang ditutup sepanjang Januari 2020 sampai Februari 2021. Kerugian yang ditimbulkan mencapai Rp 114, 9 triliun pada periode 2011-2020, tentu ini bukan jumlah yang sedikit. Sepanjang 5 bulan pertama tahun 2021, KSEI melaporkan 1.491 .341 investor baru yang masuk ke pasar modal. Hal ini harus diperhatikan pemerintah Indonesia mengingat banyak masyarakat yang tertarik berinvestasi selama pandemi Covid-19, namun ironisnya masyarakat juga rentan terjerat investasi bodong.

Kenyataan banyak masyarakat yang tertipu dengan bentuk investasi sejenis menunjukkan efektifitas penawaran dan metode yang digunakan. Prasetyo dan Haryanto (2019) menjabarkan metode yang biasa dipakai adalah dengan menawarkan keuntungan yang diluar batas wajar. Dalam 1-3 bulan pertama, dana yang diinvestasikan akan kembali sesuai dengan kelipatan atau keuntungan yang telah dijanjikan. Hal ini akan meyakinkan korban utnuk berinvestasi lebih besar lagi dengan ekspektasi keuntungan berkali-kali lipat. Pada kenyataannya, justru tidak mendapatkan keuntungan atau malah kehilangan sama sekali modal yang telah disetorkan. Hal ini sangat disayangkan karena Satgas Waspada Investasi (SWI) secara rutin merilis daftar investasi bodong di Indonesia sebagai upaya untuk meningkatkan kesadaran masyarakat akan kehadiran entitas investasi bodong.

Kurangnya literasi hukum dan ekonomi masyarakat Indonesia menjadi salah satu pupuk yang menyuburkan investasi bodong. Dalam hal ini, sosialisasi dan edukasi memiliki urgensi tinggi dalam memberantas entitas-entitas investasi bodong di Indonesia. Edukasi dan sosialisasi yang dibutuhkan adalah pengembangan literasi keuangan dari pengguna jasa keuangan itu sendiri (Safitri \& Nurmiaswari, 2019). Hadirnya sosialisasi dan edukasi keuangan bagi masyarakat Indonesia, peperangan melawan investasi bodong akan jadi lebih mudah.

Tidak hanya perkara sosialisasi dan edukasi, Maraknya investasi bodong harusnya bisa diawasi oleh Otoritas Jasa Keuangan (OJK). Perkembangan sektor keuangan di Indonesia membutuhkan kehadiran OJK sebagai sebuah lembaga pengawasan yang mampu membantu kelancaran kegiatan lembaga-lembaga jasa keuangan (Amir, 2020). OJK juga berperan penting dalam pemberantasan investasi bodong di Indonesia. Satgas Waspada Investasi yang berada di bawah OJK secara rutin melaporkan entitas-entitas investasi yang sudah ditutup OJK, namun entitasentitas ini tetap terus bermunculan karena masih banyaknya masyarakat yang berminat untuk menggunakan jasa-jasa keuangan semacam ini.

Kehadiran investasi bodong menimbulkan stigma negatif masyarakat terhadap kegiatan berinvestasi. Hal ini mengakibatkan masyarakat enggan melakukan kegiatan investasi yang padahal penting bagi masyarakat itu sendiri dan lebih luas lagi bagi pertumbuhan ekonomi negara. (Pamungkas et al., 2019). Bila tidak segera ditangani, investasi bodong akan membawa kerusakan yang lebih parah bagi ekonomi nasional. Selain merugikan masyarakat secara materil, investasi bodong membawa stigma negatif masyarakat kepada kegiatan investasi secara umum yang tentu akan berdampak buruk bagi ekonomi Indonesia.

\section{Perlindungan hukum untuk masyarakat terhadap investasi bodong}

Salah satu tujuan hukum di Indonesia adalah untuk melindungi seluruh warganya dari hal-hal yang dapat merugikan. Tentu hukum Indonesia harus menjawab kebutuhan masyarakatnya akan perlindungan hukum terhadap investasi bodong, secara spesifik forex ilegal. Hadirnya hukum bukan hanya untuk mencegah terjadinya praktik investasi bodong, namun juga untuk melindungi masyarakat dari praktik investasi bodong yang eksis dalam kehidupan masyarakat Indonesia. Investasi adalah salah satu bentuk kegiatan ekonomi yang juga harus mendapat perlindungan hukum. 
Dalam praktiknya, investasi juga tergolong sebagai kegiatan jual beli. Penyedia layanan investasi dan pelanggan bisa disebut melakukan kegiatan jual beli karena memperjualbelikan produk investasi yang kedepannya diharapkan dapat mendatangkan keuntungan atau sebagai senjata untuk menghadapi inflasi. Koeswanto dan Taufik (2017) menjelaskan bahwa kegiatan perdagangan adalah penggerak utama roda ekonomi dan dalam pelaksanaannya harus mendapat perlindungan, kemanfaatan, dan kepastian hukum untuk pelaku usaha. Hal ini tentu juga sejalan dengan UUD 1945 pasal 28D ayat 1 tentang pengakuan, jaminan, perlindungan, dan kepastian hukum dan pasal 33 ayat 4 tentang usaha menjaga keseimbangan kemajuan ekonomi. Investasi dan perdagangan berperan penting dalam kemajuan ekonomi nasional. Namun tidak ada kemajuan yang dapat diharapkan bila tidak ada perlindungan negara bagi masyarakat untuk menjalankan kegiatan investasi dan perdagangan, atau justru akan memundurkan ekonomi negara. Menjamin iklim investasi di Indonesia agar tetap berjalan dengan baik adalah salah satu langkah untuk menjamin kemajuan ekonomi nasional.

Praktik investasi bodong sendiri dapat dikategorikan sebagai tindak pidana penipuan karena menggunakan tipu muslihat, dan/atau rangkaian kebohongan, menggerakkan orang lain untuk menyerahkan barang sesuatu kepadanya (penyedia layanan investasi bodong) dan dengan demikian pasal 378 KUHP berlaku. Kegiatan penghimpunan dana tanpa izin juga dapat dikenakan pidana seperti yang telah diatur oleh Pasal 46 Undang-Undang No. 10 Tahun 1998 jo Undang-Undang No. 7 Tahun 1992 tentang Perbankan. Kegiatan investasi berbasis Syariah yang tidak mendapat izin usaha dari Bank Indonesia dapat dikenakan pidana sesuai dengan Pasal 59 Undang-Undang No. 21 Tahun 2008 tentang Perbankan Syariah. Peraturan-peraturan inilah yang dapat dijadikan sebagai alat untuk melindungi masyarakat dari praktik investasi bodong.

Secara hukum, memang ada peraturan yang mengatur tentang kegiatan investasi di Indonesia, namun bentuk perlindungan yang diperlukan masyarakat bukan hanya untuk membela masyarakat setelah mengalami kerugian, tetapi juga untuk mencegah terjadinya kerugian tersebut (Mantulangi, 2017). OJK (2019) dalam siaran pers 6 September 2019 merilis daftar website atau entitas perdagangan berjangka komoditi yang tak berizin. Dalam daftar tersebut tercatat 49 nama website, perusahaan, atau entitas. Pada 14 Juli 2021 OJK (2021) juga melaporkan daftar entitas investasi ilegal yang dihentikan. Dalam daftar tersebut tercatat 11 perusahaan yang dihentikan kegiatannya. Ini menunjukkan usaha negara mencegah terjadinya kerugian masyarakat karena aktifitas investasi yang ilegal.

OJK memiliki peran penting dalam perlindungan masyarakat dalam bidang jasa keuangan dan dalam hal ini investasi. Perlindungan investor adalah salah satu wewenang yang dimiliki oleh OJK (Asriati \& Baddu, 2021). Dalam UU OJK Pasal 6, dijelaskan bahwa menjadi kewenangan OJK untuk mengatur dan mengawasi setiap jenis lembaga jasa keuangan. Proteksi kegiatan investasi di Indonesia bukan hanya berbentuk hukum positif tetapi juga berupa badan independent yang secara khusus mengurusi hal terkait. Dalam pelaksanaan kegiatan ekonomi Indonesia, salah satu komponen penting dalam ekosistem ekonomi adalah hadirnya jasa-jasa keuangan yang sehat dan bermutu. OJK hadir sebagai badan "pengawas mutu" jasa-jasa keuangan yang melakukan kegiatan usaha di Indonesia.

Edukasi bidang hukum dan ekonomi dalam hal investasi bagi masyarakat sangat krusial untuk mewujudkan iklim investasi di Indonesia yang kondusif. Fadlia dan Yunanto (2015) menjelaskan bahwa salah satu hal yang penting untuk dilakukan adalah untuk melakukan sosialisasi program pencegahan tindakan melawan hukum dalam penghimpunan dana masyarakat dan pengelolaan investasi. Sosialisasi diberikan dengan tujuan membangun awareness masyarakat akan kehadiran entitas-entitas ilegal yang menjanjikan return yang besar yang justru ternyata fiktif. Pemerintah juga memiliki peran sebagai edukator untuk menyempurnakan perlindungan hukum bagi masyarakat Indonesia. Kehadiran pemerintah sebagai edukator harus memberikan suatu edukasi 
yang teroganisir dan transformatif yang tentu akan menentukan arah pergerakan ekonomi Indonesia secara keseluruhan.

Perlindungan dalam bidang investasi bukan hanya semata-mata untuk menjamin keamanan kegiatan investasi yang dilakukan masyarakat, tetapi juga sebagai ujung tombak pertumbuhan ekonomi Indonesia. Iklim investasi yang kondusif akan melahirkan realita ekonomi nasional yang kondusif pula. Kenyataan bahwa entitas investasi bodong hadir di tengah masyarakat Indonesia membawa kesadaran bersama untuk terus melawan dan berbenah diri. Janji mendapatkan return yang besar dengan modal yang kecil menjadi permasalahan paling umum yang akhirnya menarik para investor Indonesia untuk melakukan investasi di tempat-tempat yang riskan atau bahkan betul-betul fiktif. Pemerintah harus menghadirkan layanan produk investasi yang sama atau bahkan lebih menarik dari sekedar bualan manis oknum penyedia layanan investasi bodong sebagai salah satu bentuk perlindungan bagi masyarakat. Perbaikan iklim investasi di Indonesia adalah sebuah tanggung jawab yang harus diemban bersama sebagai salah satu bentuk pengamalan kewajiban bela negara. Investasi bodong hanyalah gejala dari suatu penyakit yang lebih besar, yaitu kesejahteraan dan kedewasaan ekonomi masyarakat Indonesia. Dengan demikian, perlindungan dalam bidang investasi harus bisa membangun kesejahteraan dan kedewasaan ekonomi masyarakat.

\section{KESIMPULAN \\ Kesimpulan}

Kegiatan investasi secara khusus dan penghimpunan dari dana masyarakat secara umum diatur oleh hukum positif Negara Indonesia. Kegiatan investasi dan penghimpunan dana dari masyarakat diatur di dalam Pasal 16 ayat 1 UU No. 10 Tahun 1998 jo Nomor 7 Tahun 1992 Tentang Perbankan. Peraturan ini menyatakan bahwa kegiatan menghimpun dana dari masyarakat dalam bentuk simpanan wajib harus terlebih dahulu memperoleh izin usaha dari Bank Indonesia. Pelanggaran terhadap peraturan tersebut juga diatur dalam Pasal 46 undangundang tersebut yang menyatakan bahwa: "Barang siapa menghimpun dana dari masyarakat dalam bentuk simpanan tanpa izin usaha dari Pimpinan Bank Indonesia sebagaimana dimaksud dalam Pasal 16, diancam dengan pidana penjara sekurang-kurangnya 5 (lima) tahun dan paling lama 15(lima belas) tahun serta denda sekurang-kurangnya Rp10.000.000.000,00 (sepuluh miliar rupiah) dan paling banyak Rp 20.000.000.000,00 (dua puluh miliar rupiah)."

Bentuk perlindungan hukum Negara Indonesia bagi masyarakat dalam menghadapi investasi bodong (forex ilegal) adalah hadirnya undang-undang yang mengatur tentang sanksi terhadap penyelenggara penghimpunan tanpa izin seperti yang diatur oleh Pasal 46 Undang-Undang No. 10 Tahun 1998 jo Undang-Undang No. 7 Tahun 1992 tentang Perbankan. Selain itu, kegiatan investasi berbasis Syariah juga mendapatkan perlindungan hukum dalam Undang-Undang No. 21 Tahun 2008 tentang Perbankan Syariah. Selain daripada hukum positif yang berlaku di Indonesia, perlindungan hukum yang bersifat preventif juga dilakukan dengan membentuk Otoritas Jasa Keuangan (OJK) yang menurut Pasal 6 Undang-Undang No. 21 Tahun 2011 tentang Otoritas Jasa Keuangan berkewenangan untuk mengatur dan mengawasi setiap jenis lembaga jasa keuangan.

Menciptakan iklim investasi yang optimal juga dapat dikatakan sebagai bentuk perlindungan hukum Negara bagi masyarakatnya karena dengan iklim investasi yang optimal, ekonomi Negara juga dapat berjalan dengan baik dan lancar yang tentu akan berpengaruh bagi kehidupan masyarakat Indonesia. Usaha menciptakan iklim investasi yang optimal ini juga sejalan dengan amanat UUD NRI 1945 pasal 33 ayat 4 tentang usaha menjaga keseimbangan kemajuan ekonomi.

Penegakkan hukum investasi Indonesia akan memberikan perlindungan bagi masyarakat dari penipuan berkedok investasi. Secara hukum, investasi bodong adalah sebuah pelanggaran pidana 
dan perdata. Bukan hanya melakukan penipuan, investasi bodong juga melanggar perjanjian yang telah disepakati dengan korban. Investasi bodong adalah perbuatan melawan hukum yang harus diberantas dan ditindaklanjuti. Masyarakat juga harus berperan aktif dalam melaporkan dan mengawasi entitas-entitas investasi yang mencurigakan.

Edukasi hukum dan finansial bagi masyarakat awam adalah ujung tombak pemberantasan investasi bodong. Masyarakat harus bisa tau cara membedakan mana investasi yang sehat dan yang tidak sehat. Janji manis investasi bodong memang menarik, namun edukasi hukum dan finansial akan memberikan kekebalan bagi masyarakat dalam menghadapi penyebaran investasi bodong.

\section{Saran}

Diharapkan kedepannya masyarakat dapat membedakan mana investasi yang legal dan yang bodong. Hal itu dapat terjadi bila masyarakat teredukasi soal ekonomi dan hukum. Ini menjadi tanggung jawab bersama pemerintah, penyelenggara investasi, dan akademisi. Demi mewujudkan penegakkan hukum yang adil dan dapat melindungi masyarakat dari investasi bodong yang merugikan, semua pihak harus dapat bekerja sama dengan baik.

\section{Ucapan Terima Kasih}

Penulis mengucapkan terima kasih kepada semua pihak yang terlibat dalam penulisan artikel ini terutama pada orang tua, saudara, dan rekan-rekan. Tidak lupa juga terima kasih kepada bapak Yuwono Priatno S.H., M.H. yang telah membimbing penulis selama penyusunan artikel ini. Penulis juga ingin mengucapkan terima kasih kepada tim SENAPENMAS yang selalu kooperatif untuk membantu penulisan artikel ini.

\section{REFERENSI}

Ahmad, K. (2004). Dasar-dasar Manajemen Investasi dan Portofolio. PT Rineka Cipta, Jakarta. Amir. M.F. (2020). Peran dan Fungsi Otoritas Jasa Keuangan (OJK) Dalam Sistem Keuangan di Indonesia (Perspektif Hukum Islam). Al-Amwal: Journal of Islamic Economic Law. 5(1), 59-71.

Asriati \& Baddu, S (2021). Investasi Online Reksadana: Aspek Hukum dan Perlindungan Bagi Investor selaku Konsumen. Pleno Jure, 10(1), 38-53.

CNN Indonesia. (2021, April 13). 390 Investasi dan 1.200 Fintech Bodong Ditutup Selama 2020. CNN Indonesia. https://www.cnnindonesia.com/ekonomi/20210413110104-78629150/390-investasi-dan-1200-fintech-bodong-ditutup-selama-2020 .

Fadlia \& Yunanto (2015). Peran Otoritas Jasa Keuangan (OJK) dalam Perlindungan Hukum Bagi Investor Atas Dugaan Investasi Fiktif. Law Reform, 11(2), 207-215.

Hidayat, A.A.N. (2021, Juni 21). KSEI Catat Investor Saham Tumbuh 41,82 Persen Per Akhir Mei 2021. Tempo. https://bisnis.tempo.co/read/1474721/ksei-catat-investor-sahamtumbuh-4182-persen-per-akhir-mei-2021.

Horne, J.C.V. (1994). Dasar-dasar Manajemen Keuangan jilid 2. Erlangga, Jakarta.

Indonesia Stock Exchange. (2021, Maret 12). Pentingnya berinvestasi [Video]. YouTube. https://www.youtube.com/watch?v=D9VivZqW2UA.

Kamus Besar Bahasa Indonesia (KBBI). (n.d.). Investasi. Dalam Kamus Besar Bahasa Indonesia (KBBI). Diakses pada 30 Agustus 2021, dari https://kbbi.kemdikbud.go.id/entri/investasi .

Kitab Undang-Undang Hukum Pidana.

Koeswanto, E.S. \& Taufik, M. (2017). Perlindungan Hukum Terhadap Investor yang Melakukan Investasi Virtual Currency (centcoin dan bitcoin). Living Law, 9(1), 201-217.

Mantulangi, N. (2017). Kajian Hukum Investasi dan Perlindungan Terhadap Korban Investasi Bodong. Lex Administratum, 5(1), 108-115. 
Otoritas Jasa Keuangan, (2019, September). Siaran Pers Satgas Temukan 123 Fintech Lending Ilegal, 30 Gadai Swasta dan 49 Entitas Penawaran Investasi Tanpa Izin. Satgas Waspada Investasi, Otoritas Jasa Keuangan. https://www.ojk.go.id/id/berita-dan-kegiatan/siaranpers/Pages/Siaran-Pers-Satgas-Temukan-123-Fintech-Lending-Ilegal,-30-Gadai-Swastadan-49-Entitas-Penawaran-Investasi-Tanpa-Izin.aspx .

Otoritas Jasa Keuangan, (2021, Juli). Siaran Pers: Satgas Waspada Investasi Perkuat Penegakan Hukum Berantas Pinjaman Online Ilegal. Satgas Waspada Investasi, Otoritas Jasa Keuangan. https://www.ojk.go.id/id/berita-dan-kegiatan/siaran-pers/Pages/SatgasWaspada-Investasi-Perkuat-Penegakan-Hukum-Berantas-Pinjaman-Online-Ilegal.aspx .

Pamungkas, A.S., Budiono, H., \& Wiyanto, H., Widjaya, H. (2019). Pelatihan Pengenalan Investasi Reksadana untuk Pelajar SMK Ariya Metta. Sabdamas. 1(1), 133-140.

Prasetyo, H. \& Haryanto, I. (2019). Pendampingan Strategi Menangkal Penipuan Investasi Bodong di Kelurahan Pangkalan Jati. Sabdamas, 1(1), 320-324

Primantari, A.A.A. \& Sarna, K. (2014). Upaya Menanggulangi "Investasi Bodong" di Internet. Kertha Semaya: Jurnal Ilmu Hukum, 2(3), 1-5.

Safitri, H. \& Nurmiaswari H. (2019). Pengembangan Literasi Keuangan Dengan Pengetahuan Tentang Investasi Bodong Di Desa Limbung Dusun Mulyorejo. Buletin Al-Ribaath, 16(2), $69-73$

Soekamto, S. \& Mamudji, S. (2007). Penelitian Hukum Normatif: Suatu Tinjauan Singkat. Raja Grafindo Persada, Jakarta.

Undang-Undang Dasar Negara Republik Indonesia tahun 1945.

Undang-Undang No. 10 Tahun 1998 jo Undang-Undang No. 7 Tahun 1992 tentang Perbankan.

Undang-Undang No. 11 Tahun 2020 tentang Cipta Kerja

Undang-Undang No. 21 Tahun 2008 tentang Perbankan Syariah.

Undang-Undang No. 21 Tahun 2011 tentang Otoritas Jasa Keuangan.

Undang-Undang Nomor 25 Tahun 2007 Tentang Penanaman Modal

Warenza, M. (2021, Agustus 5). Alamak! Kerugian Investasi Bodong Capai Rp 117 T. CNBC Indonesia. $\quad$ https://www.cnbcindonesia.com/investment/20210805111927-21266285/alamak-kerugian-investasi-bodong-capai-rp-117-t .

Yanwardhana, E. (2021, April 15). Astaga! Investasi Bodong di RI Bikin Investor Tekor Rp 114 T. CNBC Indonesia. https://www.cnbcindonesia.com/investment/20210415081811-21237981/astaga-investasi-bodong-di-ri-bikin-investor-tekor-rp-114-t

Yugo, I. (2021, Maret 24). Viral Siswi SMA Tipu Warga hingga Pejabat Modus Investasi, Rp2,6 Miliar Dibawa Kabur. https://news.okezone.com/read/2021/03/24/340/2383476/viral-siswi-sma-tipu-wargahingga-pejabat-modus-investasi-rp2-6-miliar-dibawa-kabur . 